\title{
Microbial composition with the properties of plant growth promoter, biofertilizer and biological fungicide
} Mikhailouskaya N.A. ${ }^{1}$, Voitka D.V. ${ }^{2}$, Yuzefovitch E.K. ${ }^{2}$

${ }^{1}$ RUP “Institute for Soil Science and Agrochemistry", Minsk; ${ }^{2}$ RUP “Institute of Plant Protection”, Priluki, Belarus E-mail: bionf1@yandex.ru,voitka@tut.by

Key message. Microbial composition A. brasilense $+B$. circulans $+T$. longibrachiatum (MC) is effective inoculant for grain crops growing in erosion agrolandscaps. MC reveals the properties of plant growth promoter, biological fertilizer and biological fungicide. Poly functional positive action of three-component MC resulted in the increase of grain crops yield and improvement of its quality in stress conditions in erosion agrolandscaps.

Keywords: microbial composition, growth promotion, biocontrol, barley, rye, crop yield

Actual technique for making crop production ecological is application of microbial preparation of highly action spectrum. The purpose of investigation was to estimate microbial composition's (MC) potential to increase crop yield and its quality as well as to protect grain crops from root infections. Influence of rhizobacteria on plant developments at earlier phases of ontogenesis was studied in laboratory experiments. Effectiveness of MC was studied in field experiments with spring barley and winter rye growing on sod-podzolic eroded soils. Microbial composition contains three components: Azospirillum brasilense 2(b)3 + Bacillus circulans K-81 + Trichoderma longibrachiatum L-7. Plant growth stimulation is one of the most important effects of inoculation. Combined application of rhizobacteria A. brasilense $+B$. circulans (in vitro) induced significant hormonal effect. Roots dry mass was increased by $28 \%$, roots length per plant - by $25 \%$, stem dry mass - by $33 \%$. Treatment of barley sowing by microbial composition provided the reduction of root rot incidence by $52.0-58.0 \%$, disease development - in $2.6-2.9$ times, biological efficiency was $66.3-69.5 \%$. Treatment of winter rye sowing resulted in the reduction of disease incidence by $42.4-45.0 \%$, disease development - in $2.0-2.6$ times, biological efficiency $-50.2-61.2 \%$ accordingly to soil-erosion catena. Application of microbial composition provided barley grain responses: $5.2 \mathrm{c} \mathrm{ha}^{-1}(9.3 \%), 4.9 \mathrm{c} \mathrm{ha}^{-1}(9.2 \%)$ and $2.5 \mathrm{c}$ $\mathrm{ha}^{-1}(4.8 \%)$, winter rye responses $-3.8 \mathrm{c} \mathrm{ha}^{-1}(7.0 \%), 3.8 \mathrm{c} \mathrm{ha}^{-1}(7.4 \%)$ and $4.5 \mathrm{c} \mathrm{ha}^{-1}(9.8 \%)$ on watershed, weakly- and moderately eroded soils. Effective biological control of root infections is of great importance in order to prevent crop yield losses. Reliable increase of protein content in grain was obtained. The components of microbial composition directly or indirectly improve adaptation potential of grain crops growing in erosion agrolandscapes. Rhizobacrteria stimulate root development and mobilization of nitrogen, phosphorus and potassium from atmosphere, soil and fertilizers. Antagonistic fungi provide effective biological control of pathogens. Microbial composition reveals the properties of plant growth promoter, biological fertilizer and biological fungicide. Poly functional positive action of three-component microbial inoculant resulted in the increase of grain crops yield and improvement of its quality in stress conditions of cultivation in erosion agrolandscaps.

\section{Микробная композиция, сочетающая свойства регулятора роста, биоудобрения и биофунгицида Михайловская Н.A. ${ }^{1}$, Войтка Д.В. ${ }^{2}$, Юзефович E.K. ${ }^{2}$}

${ }^{1}$ Институт почвоведения и агрохимии, Минск, Беларусь; ${ }^{2}$ Институт защиты растений, Прилуки, Беларусь

\begin{abstract}
Аннотация. Микробная композиция A. brasilense+B. circulans + T. longibrachiatum (MК) - эффективныий инокулянт для ячменя ярового и ржи озимой при воздельвании на эродированных почвах. Компоненты МК стимулируют развитие корневой системы растений, мобилизацию азота, фосфора и калия из атмосферы, почвы и удобрений, обеспечивают эффективный биологический контроль фитопатогенов. Аддитивное действие компонентов МК повышает урожайность и качество продукции зерновых культур.
\end{abstract}

Ключевые слова: микробная композиция, стимуляия роста, биоконтроль, ячмень, рожь

Актуальным приемом экологизации растениеводства является применение микробных препаратов широкого спектра действия. Цель работы - оценка потенциала микробной композиции (МК) по повышению урожайности и качества продукции, защите зерновых культур от корневых инфекций. Влияние ризобактерий на развитие растений на ранних этапах онтогенеза изучено в in vitro экспериментах. Эффективность МК на посевах ячменя ярового и ржи озимой установлена в полевом стационаре на эродированных почвах. Микробная композиция включает штаммы грибаантагониста Trichoderma longibrachiatum L-7, азотфиксирующей (Azospirillum brasilense 2(b)3 и калиймобилизующей (Bacilus circulans K-81) ризобактерий. Совместное применение ризобактериий A. brasilense + B. circulans оказывало значимый гормональный эффект: стимуляция сухой массы корней - 28\%, суммарной длины корешков/растение $25 \%$, сухой массы проростков - 33\%. Обработка посевов МК снижала распространенность корневой гнили ячменя ярового на 52,0, 54,0 и 58,0\%, развитие болезни (восковая спелость) - в 2,9, 2,8 и 2,6 раза, биологическая эффективность МК - 69,5, 66,3 и 67,6\%, на посевах ржи озимой (молочная спелость) - на 45,0\%, 42,4\% и 42,9\%, развитие болезни - в 2,6, 2,1 и 2,0 раза, биологическая эффективность - 61,2\%, 52,5\% и 50,2\% на неэродированной, слабо- и среднеэродированной почвах соответственно. Применение МК обеспечило прибавки урожайности зерна ячменя ярового - 5,2 (9,3\%) и 4,9 (9,2\%) ц/га, ржи озимой - 7,0\%, 7,4\% и 9,8\% на неэродированной, слабо- и среднеэродированной почвах. При использовании МК отмечено достоверное повышение содержания белкового азота в зерне ячменя ярового и ржи озимой. Компоненты МК прямо или косвенно повышают адаптивный потенциал зерновых культур при возделывании на эродированных почвах. Бактериальные компоненты стимулируют развитие корневой системы растений и улучшают мобилизацию азота, фосфора и калия из атмосферы, почвы и удобрений. Грибной компонент МК обеспечивает эффективный биологический контроль фитопатогенов. Полифункциональное положительное действие составных компонентов микробной композиции повышает продуктивный статус, урожайность и качество продукции зерновых культур в условиях стресса при возделывании в эрозионных агроландшафтах. 